\title{
The Development of Football Basic Skill Learning Model
}

\author{
Slamet Riyadi \\ Faculty of Teacher Training and \\ Education Sebelas Maret University \\ Surakarta, Indonesia \\ slametriyadi70@staff.uns.ac.id
}

\author{
Rumi Iqbal Doewes \\ Faculty of Teacher Training and \\ Education Sebelas Maret University \\ Surakarta, Indonesia \\ King.doewes@staff.uns.ac.id
}

\author{
Fadilah Umar \\ Faculty of Teacher Training and \\ Education Sebelas Maret University \\ Surakarta, Indonesia \\ Fadilpok@gmail.com
}

\begin{abstract}
- this study was carried out based on the fact that there were optimal technique for student's learning function which lead lecturers into the implementation of a scientific approach-based learning models, a model centered on the lecturer. The aim and objective of this research study is to develop an ASSURE design-based football learning model for students of POK FKIP UNS. This study made use of qualitative and quantitative approaches, as well as the research and development model. The second stage of this research study is the development of Adobe Flash Player-based media. Product evaluation by academics and football practitioners, obtained an average score of 72.38. Product testing was carried out in small and large groups, with small group comprising of 12 students and while the large group comprised of 54 students. Data was obtained by the use of questionnaires. The test results for the small group was $83.19 \%$ while that of the large group was $84.5 \%$. The third stage was called product effectiveness test which compared two treatment groups using pretest and posttest design. The difference value of ball feeling test in the

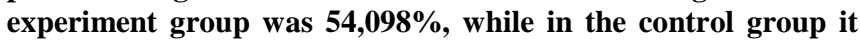
was $46,279 \%$. The value of the dribbling test in the experimental group was $31.858 \%$, and $29.032 \%$ in the control group. The values of the graduation tests in the experimental and control group were $98.324 \%$, and $95 \%$ respectively. The value of the shooting test in the experimental group was $73.810 \%$, and the control group was $68.724 \%$. It can be concluded that the product is effective and capable of improving the mastery of football basic skills and techniques on POK FKIP UNS students.
\end{abstract}

Keywords-development, ASSURE design, football learning

\section{INTRODUCTION}

The technique used in teaching athletes football learning were usually implemented using the drill approach. This teaching approach was usually boring for football players during training. Lecturers didn't provide the best training with the implemented scientific approach-based learning models. The learning process carried by teachers was found to provide less active students. The patterns and football learning model such as subjects was necessary to make changes in the learning process. The learning process should be able to maximize students' efforts to be more active and also support human resources establishment.

ASSURE design-based football learning is an alternative learning model that can be implemented to maximize the role of students in the learning process. This learning system model was developed to create an effective and efficient, learning activities capable of taking advantage of the media and technology.

A sequential step-by-step technique used in implementing the ASSURE design learning model includes the following stages: 1) Analyze leaner characteristic, 2) Objective, 3) Selecting the method, media and leaning materials, 4) Utilizing the materials, 5) learner participation, and 6) Evaluation and revision. The learning design model is very simple and can be easily implemented by teachers or lecturers to ensure an improved learning outcome, motivate learning processes, improve memory retention, and to encourage students to apply knowledge and skills learned. This learning process was considered successful as it improved students' performance. ASSURE design-based football learning model needs to be properly developed and implemented to enable lecturers use it as a reference while teaching students basic football skills.

\section{METHODOLOGY}

This research made use of the Research and Development ( R \& D) approach, along with the qualitative and quantitative approach in developing the ASSURE design-based football learning model. ASSURE design comprises of six steps, namely: A - Analyze learner characteristics ; S - State performance objectives; $\mathrm{S}$ - Select method, media and leaning materials; $\mathrm{U}$ - Utilize materials; $\mathrm{R}$ - Require learner participation; E - Evaluation and revision [13].

The Research and Development (R \& D) approach is made up of ten steps: Preliminary Study, Research Planning, Design Development, Preliminary Field Test, Revision of Limited Field Test Results, Main Field Test, Revision of Wider Field Test Results, Feasibility Test, Final Revision of Feasibility Test Results, and Dissemination and Implementation of Final Product [3]. These steps are essential to obtain an ASSURE design based football learning model.

The mechanism of the overall measures undertaken to develop a ASSURE design-based football learning model are as follows:

1. Conduct analysis of the characteristics and needs of football learning materials. Carry out literature studies on student characteristics. Conduct reviews on football curriculum and learning materials. Review the previous studies related to the learning model, and the field situation including classroom conditions, institutions, number and condition of students, facilities and infrastructure, and the prevailing teaching practices. 
2. Prepare and develop ASSURE design-based football learning model that will be applied to the students. Draft a ASSURE design-based football learning model in accordance with the analysis results of the characteristics and material needs of the students.

3. Validate the related football learning skills from experts. In carrying out this technique, experts in the fields of curriculum, media and technology, research and development, and physical learning model especially football learning should be consulted. The validation covers the material's, heights and depths, fitness model, type and evaluation system. The learning models are improved after obtaining the right ideas from experts.

4. Conduct a field test. Initial field tests should be conducted with limited subjects (users), to assess how far the learning model can properly be used. This test is easy, and should be in accordance with the expected learning objectives.

5. Repairs and revisions based on the initial field test results. Preliminary test results were analyzed, evaluated and consulted with experts to get inputs.

6. The trial of revision results with a larger subject. At this stage, the trial is conducted after repair and it is based on the initial trial results.

7. Repairs and revisions is based on the results of trials with wider subjects (users) (main field test). Initial test results were analyzed, evaluated with the result analyzed by experts to get inputs based on the implementation of trials with wider subjects (main field test).

8. Model feasibility testing with wider subjects (main field test) through experimental research. Model feasibility test is the implementation of the already prepared ASSURE design-based football learning model.. The model's feasibility test is basically the main trial. The purpose of the feasibility test is to assess if the learning objectives achieved is used correctly. It is also used to determine if it is easy, interesting and appropriate to use.

9. Repair and final revision based on results of feasibility test of football learning model.

10. The final product is ASSURE design-based football learning model that can disseminated and implemented.

The steps taken at the development stage is detailed in the flow scheme below:

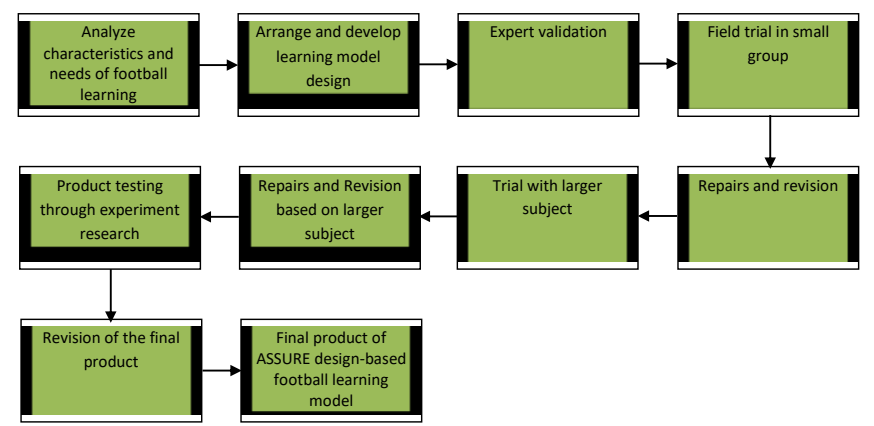

Fig. 1. Illustration Steps Research

This study prepared the draft and models of ASSURE design-based football learning for POK FKIP UNS students. The materials used to design the learning model used to customize the football subjects curriculum to the semester lesson plan has been set. The design and models of ASSURE design- based football learning for POK FKIP UNS students are as follows: (1) The ball felling learning model ; (2) The throw-in and heading learning model; (3) The dribbling learning model; and (4) The passing learning model.

Each Model was tested on small and large groups of students during the 2015 third semester of POK FKIP UNS with the results of the ASSURE Design-Based Football Learning Model as follows:

\section{A. Analysis of Characteristics of Students / Student (Analyze Learners Characteristic)}

1. At this stage, the football course was carried out 3 to 4 times, three sessions were carried out in the classroom while the remaining season was carried out in the field. These seasons were used to provide a detailed explanation of the basic football learning skills that will enable students get a clear picture of the lectures in one semester.

2. Data was collected and analyzed by lecturers on students participating in the study. using already prepared test instruments.

3. Data was collected from common characteristics, motivation, study habits, and the initial ability of cognitive and affective aspects made at the 2 nd meeting. The data collection on initial ability of skills aspects was performed at the 3rd meeting. In the field test the measurement capabilities of juggling, bottom passing and upper passing, dribbling, and heading are included.

4. The results of the obtained data was then analyzed to determine the characteristics of each student, and also used to split some of the characteristics which included a member of the group (team) for further learning. Each group (team) is expected to consist of several heterogeneous characteristics of students that will affect the atmosphere in the learning process. Meanwhile, between one group and another group an expected or uneven balance is expected, so that at the end of the lesson the success level of the learning process will be known.

5. Some students' characteristics were unidentifiable such as gender, hobby, sport coaching achievements practiced, football knowledge, ability level of football skills, motivations, football experience, etc. all of which will affect the football learning process.

6. The results of some of the above steps produced data as listed in table 1 .

7. After the identification of student's characteristics,learning groups were formed. The 4th meeting described the working steps for each group which was used to make preparations for further learning

\section{B. Establish Learning Objectives (State Objectives)}

Knowing the students' characteristics and establishing study groups will be helpful in determining the right measures used to achieve the various learning objectives. Learning objectives to be achieved in the football course is adjusted to the core competencies and learning indicators set on the syllabus or semester lesson plans of the football course. In ASSURE design based football learning on POK FKIP UNS students, the learning objectives defined are as follows: 
1. Honesty, sportsmanship, discipline, fairness, respect, and cooperation.

2. Adding and develop student's football knowledge.

3. Enhancing students' football feeling skills.

4. Enhancing students' throw in and heading skills.

5. Enhancing students' dribbling skills.

6. Enhancing students' passing skills.

7. Develop and design ball control, throw-in, heading, passing and dribbling learning skills.

\section{RESULTS AND DISCUSSION}

TABLE I. OVERVIEW RESULTS

\begin{tabular}{|c|c|c|}
\hline No & Component & Invention \\
\hline 1 & $\begin{array}{l}\text { Introduction Stage } \\
\text { Interview with football } \\
\text { coaches at POK FKIP } \\
\text { UNS on basic football } \\
\text { technique, mastery of } \\
\text { POK FKIP UNS } \\
\text { students (n=2) with } 4 \\
\text { points questions. }\end{array}$ & $\begin{array}{l}\text { Mastery of football technique is } \\
\text { not good, at POK FKIP UNS } \\
\text { there has not been learning } \\
\text { program specifically to teach } \\
\text { football technique. }\end{array}$ \\
\hline \multirow[t]{3}{*}{2} & $\begin{array}{l}\text { Developmental Stage } \\
\text { a. The evaluation } \\
\text { results of football } \\
\text { experts }(\mathrm{n}=3) \\
\text { with the } \\
\text { instrument number } \\
\text { of } 20 \text { ball feeling } \\
\text { questions, } 15 \\
\text { dribbling questions, } \\
20 \text { passing } \\
\text { questions, } 20 \\
\text { shooting questions }\end{array}$ & $\begin{array}{l}\text { a. The evaluation results of the } \\
\text { third party football experts } \\
\text { were obtained with a } \\
\text { percentage of } 72.38 \% \text {, so that } \\
\text { learning model can tried out. } \\
\text { b. Input from the football experts, } \\
\text { learning model design still } \\
\text { required product pictures to } \\
\text { be added for a clearer and } \\
\text { learning program design which } \\
\text { must be adjusted with the } \\
\text { theory of learning and } \\
\text { techniques of football game. }\end{array}$ \\
\hline & $\begin{array}{l}\text { b. Small group testing } \\
\text { of }(n=12) \text { with the } \\
\text { instrument number } \\
\text { of } 60 \text { questions. }\end{array}$ & $\begin{array}{l}\text { The testing result of small } \\
\text { group was obtained with a } \\
\text { percentage of } 83.19 \% \text {, so that } \\
\text { learning model can be continued } \\
\text { to a larger testing stage. }\end{array}$ \\
\hline & $\begin{array}{l}\text { c. Large group } \\
\text { testing }(\mathrm{n}=54) \text { with } \\
\text { the instrument } \\
\text { number of } 60 \\
\text { questions. }\end{array}$ & $\begin{array}{l}\text { From the large group testing } \\
\text { result a percentage of } 84.5 \% \text { was } \\
\text { obtained, so that learning model } \\
\text { can be continued to stage of } \\
\text { product effectiveness test. }\end{array}$ \\
\hline 3 & $\begin{array}{l}\text { Products effectiveness } \\
\text { test } \\
\text { Different value }\end{array}$ & 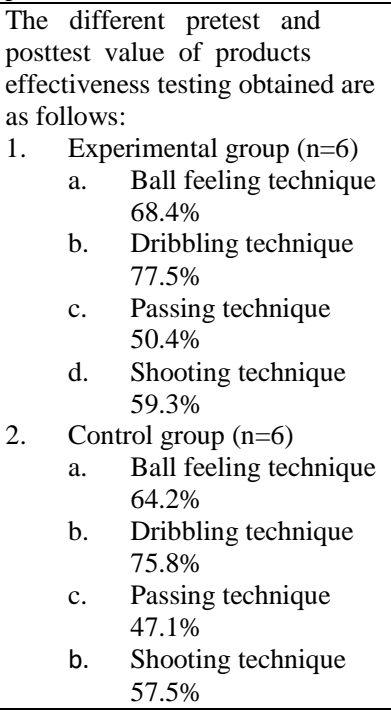 \\
\hline
\end{tabular}

Based on the analysis of table 1, it can be seen that at the introduction stage needs analysis was conducted by interviews. Needs analysis is very essential owing to its ability to identify and solve a problem. Need analysis is a collection of early information against the different conditions in the field and conditions intended, for problem solving [3]. Interview result is football technique not properly implemented in POK FKIP UNS with no special learning programs about the football technique. Development stage was conducted and evaluated by football experts with a percentage of $72.38 \%$. The academic advice comprises of (1) a learning technique which describes an unambiguous learning purpose; (2) the implementation procedures of football techniques learning with a more clarified training model; (3) the preparation of learning model needs to adapt to the facilities and infrastructure in the field. Advice from the football practitioners include (1) learning model should be from the easy stage before moving to the difficult stage; (2) learning physical leading should be made a learning technique; (3) learning must be adjusted to the learning condition. Besides the experts evaluation at the development stage, evaluation was also conducted on products with testing on small and large groups. Try out stage was used to know students' opinion related to the product training model development. Information was obtained from students using questionnaires with a total of 60 questions. Small and large group testing was carried out using a sample of 12 and 54 students. The testing results is in the percentages of $83.19 \%$ for small groups and $84.5 \%$ for large group. This means that the product of learning model development is acceptable to POK FKIP UNS students. It also indicates their readiness to undergo effectiveness testing a test used to determine the effectiveness of a product. The pretest and posttest experimental design was used to design the proposed system. The pretest design was used to measure the initial conditions, while the posttest control group was to measure the untreated control group. Based on a comparison this percentage which showedan increase in test results, it can be seen that the sample group is more effective than the control group.

TABLE II. DATA OF PRE-TEST AND POST-TEST RESUlT

\begin{tabular}{|c|c|c|c|c|c|c|c|}
\hline \multirow{2}{*}{ Group } & \multirow{2}{*}{ Testing } & \multicolumn{2}{|c|}{ Test result } & \multirow{2}{*}{$\begin{array}{c}\text { Differ } \\
\text { ent } \\
\text { value }\end{array}$} & \multirow{2}{*}{$\mathbf{T}_{\text {count }}$} & \multirow[b]{2}{*}{$\mathbf{T}_{\text {table }}$} & \multirow{2}{*}{$\begin{array}{c}\text { Conclu } \\
\text { sions }\end{array}$} \\
\hline & & $\begin{array}{l}\text { Pre- } \\
\text { test }\end{array}$ & $\begin{array}{c}\text { Post- } \\
\text { test }\end{array}$ & & & & \\
\hline \multirow{4}{*}{$\begin{array}{l}\text { Experi } \\
\text { ment group }\end{array}$} & Ball feeling & 69 & 98 & 29 & 12.7583 & 2,571 & Sign. \\
\hline & Dribbling & 124 & 160 & 36 & 12,9455 & 2,571 & Sign. \\
\hline & Passing & 180 & 355 & 175 & 13,3243 & 2,571 & Sign. \\
\hline & Shooting & 245 & 410 & 165 & 12,9437 & 2,571 & Sign. \\
\hline \multirow{4}{*}{$\begin{array}{l}\text { Control } \\
\text { group }\end{array}$} & Ball feeling & 61 & 94 & 33 & 12,8778 & 2,571 & Sign. \\
\hline & Dribbling & 113 & 149 & 36 & 12,4708 & 2,571 & Sign. \\
\hline & Passing & 160 & 340 & 180 & 13,2939 & 2,571 & Sign. \\
\hline & Shooting & 210 & 365 & 155 & 13,2993 & 2,571 & Sign. \\
\hline
\end{tabular}

Table 2 explains the significance test of product training model development. Based on the table 2, for every group is count larger than table, so can be concluded that data significance.

This research produced a ASSURE design-based football learning models in student sport. The model comprisesof: (1) ASSURE design-based ball felling learning model, (2) ASSURE design-based throw in and heading learning model, (3) ASSURE design-based dribbling learning model, and (4) ASSURE design-based passing learning model. This research 
will be followed up with a research study on Adobe Flash Player-based media in Learning Basic Football. Based on the research result and data analysis obtained, the research conclusions which is a product of training model development can also be an alternative learning model to maximize the role of students in mastering the basic football skills.

\section{REFERENCES}

[1] Atwi Suparman. Desain Instruksional Modern. Edisi Keempat. Jakarta: Penerbit Erlangga. 2014.

[2] Benny A. Proibadi. Model ASSURE untuk Mendesain Pembelajaran Sukses. Jakarta: Dian Rakyat. 2011.

[3] Borg, R. Walter and Gall, Meredith Damien. Educational Research. Fourth Edition. New York: Longman Inc. 1983.

[4] B. Joyce, M. Weil, dan E. Calhoun. Models of Teaching, Eigth Edition. New Jersey, USA: Pearson Education, Inc. 2009.

[5] D. Mielke. Dasar-Dasar Sepakbola Terjemahan Football Fundamentals. Bandung: Pakar Raya Pustaka. 2007.

[6] Gall, D. Meredith, Gall Joyce P., \& Borg Walter R. Educational Research. United States of America: Person Education, Inc. 2007.
[7] L. R. Gay, E. Geoffrey, Mills, dan P. Airasian. Educational Research. Competencies for Analysis and Applications. New Jersey: Pearson. 2012 .

[8] J. A. Luxbacher, Sepakbola. Jakarta: PT. Grafindo Media Pratama, 2001.

[9] N. Putra. Research\& Development. Penelitian dan Pengembangan: Suatu Pengantar. Jakarta: PT Rajagrafindo. 2012.

[10] P. Setyosari. Metode Penelitian Pendidikan dan Pengembangan. Jakarta: Prenadamedia Group. 2015

[11] C. Rita, Richey, J. D. Klein, dan W. Monica Tracey. The Instructional Design Knowledge Base: Teory, Research, and Practice. New York: Routledge. 2011.

[12] T. Scheunemann, Dasar-Dasar Sepakbola Modern. Malang: Penerbit Dioma 2008.

[13] Sharon E. Smaldino, Deborah L. Lowther, \& James D. Russell. Instructional Technology \& Media For Learning terjemahan Teknologi Pembelajaran dan Media untuk Belajar, Edisi Kesembilan.Jakarta: Kencana Prenadamedia Group. 2014.

[14] Sugiyono. Metode Penelitian Pendidikan: Pendekatan Kuantitatif, Kualitatif dan R \& D. Bandung: Alfabet. 2015.

[15] Z. Arifin. Metode Pendidikan Metode dan Paradigma Baru. Bandung: Rosda. 2011. 